\title{
Effect of Procedures for Making Bacillary Suspensions on Elongation of $M$. lepraemurium in vitro
}

\author{
MASAHIRO NAKAMURA \\ (Department of Microbiology, Kurume University School of Medicine, Kurume)
}

Factors, involved in the procedures for making bacillary suspensions, affecting the elongation of $M$. lepraemurium in vitro, were studied and the following results were obtained.

1. The most significant elongations of the bacilli were observed when the bacillary suspensions were made by a mild procedure in which a leproma was cut with scissors and suspended in $0.1 \%$ bovine albumin $\mathrm{V}$ (Armour)-saline by pipetting, or was gently ground and homogenized in a mortar for one or five minutes.

2. Slight elongation took place in the cases of experiment in which partially purified bacilli or bacilli obtained from the homogenate of fifteen minutes' ground in a mortar were used.

3. There was a remarkable difference between two kinds of medium used for observing elongation phenomena; in the original Kirchner medium, elongation occurred at $\mathrm{pH} 6$ and in the enriched Kirchner medium $\mathrm{pH} 7$.

The data mentioned above, should contribute toward the experiment for cultivation and animal experiment of $M$. lepraemurium. 


\title{
鼠藾菌液作製操作の in vitro elongation に及ぼす影響
}

\author{
中 村昌弘 \\ (久留米大学医学部微生物学教室細菌学講座)
}

（受付 1972年 1 月25日）

鼠瀨菌の in vitro elongation について一連の研 究1)-5)を続行中であるが, 時々当然 elongation が起る 筈の条件でも， elongation が認められないことがある。

この原因について第一に想像されることは用いた菌液 によると思われること，次には培地に用いた血清による ものではなかろらかということである。

鼠瀨菌の in vitro elongation は微妙なる現象ではな いので,一定の条件を具備すれば $100 \%$ に例外なく elongation が起ることが観察されている。しかし，菌液の 作製条件か，鼠癩腫を採取する場合の日時によるのか， 時に elongation の程度が極めて軽度のことがある。こ の原因を菌液作製溶液，塗抹すべきスライド，塗抹後の

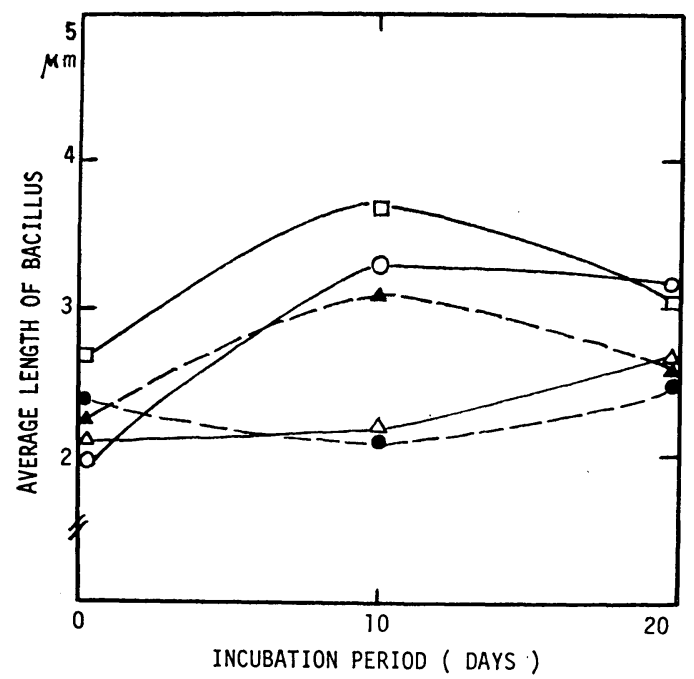

Fig. 1 Elongation curves of $M$. lepraemurium in Enriched Kirchner medium $\mathrm{pH} 6.0$

$\bigcirc$ Bacilli obtained from non-ground leproma

- Ground for one minute

$\triangle$ Ground for five minutes

$\Delta$ Ground for fifteen minutes

$\square$ Purified bacilli
乾燥度及び菌液を乾かしてから培地へ投入するまでの時 間などについて検討しているが，今回は鼠癩腫を採取し

て菌液にする場合の条件について検討した。

\section{実験材料と方法}

供試鼠癩腫 : 鼠癩菌ハワイ株（M-53）を用いた。これ は採取 4 カ月前, $\mathrm{C}_{3} \mathrm{H} / \mathrm{dd}$ マウスの皮下に接種されたも ので，採取時には小指頭大の鼠瀨腫であった。

菌液作製法 : elongation 実験に用いるための菌液の 作製法は次の 5 方法によった。まず鼠癩腫を無菌的にと り出し，滅菌シャーレに移し，これを 5 等分した。

1）非磨砕菌液：とり出した鼠瀨腫の一部を別の滅菌

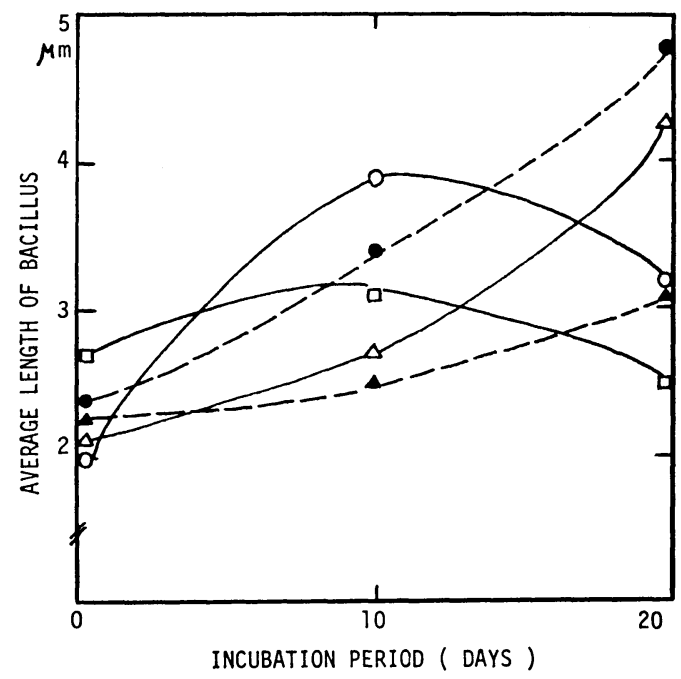

Fig. 2 Elongation curves of $M$. lepraemurium in Enriched Kirchner medium $\mathrm{pH} 7.0$ 

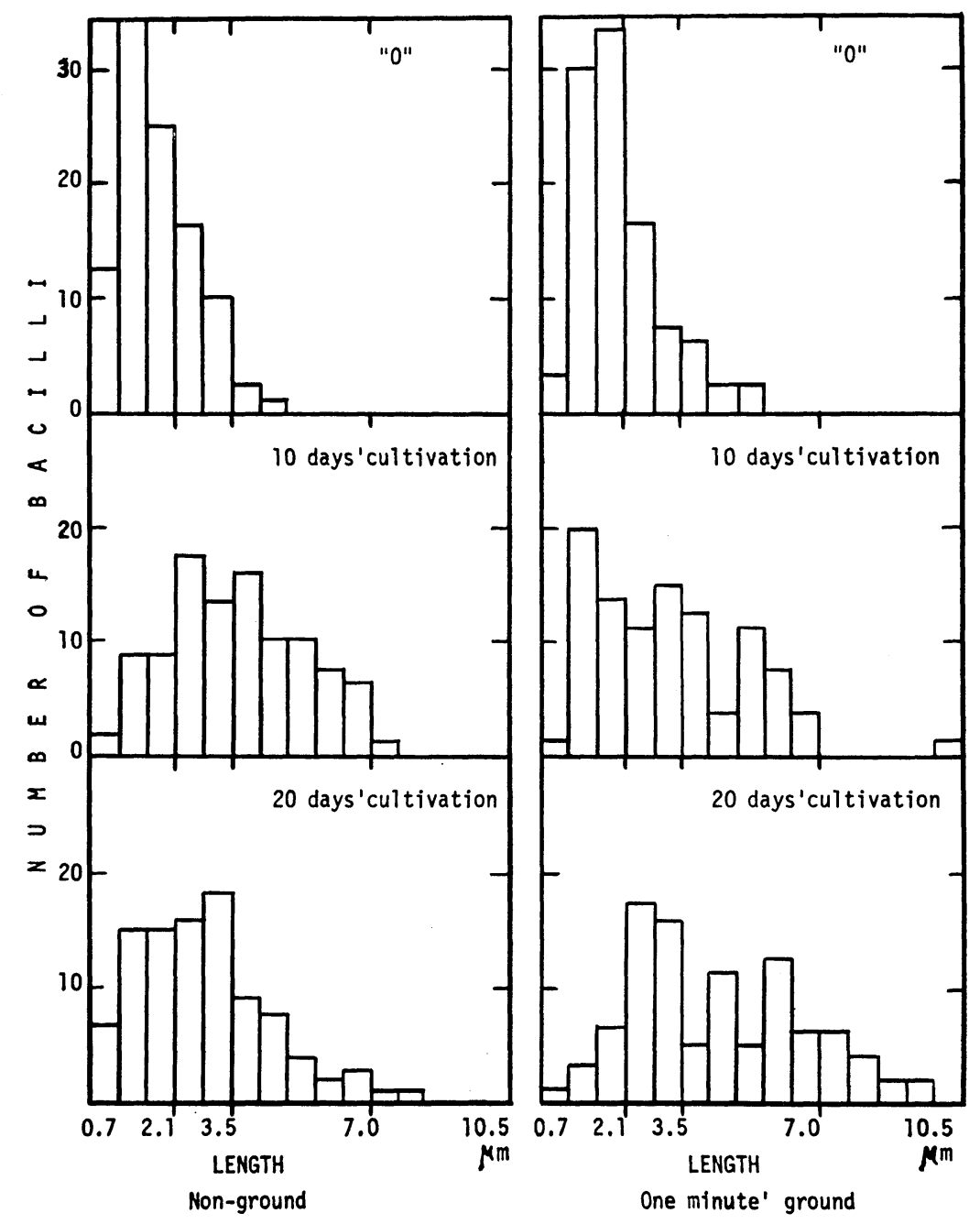

Fig. 3 Distribution of length $M$. lepraemurium

シャーレに移し, 滅菌ハサミで出来るだけ小さく細切,

これに $0.1 \%$ 牛血清アルブミンV (Armour)-生塩水を注 ぎ，更に滅菌ピペットでよく pipetting して菌液とした もので乳鉢で磨砕する操作を行なわなかったもの。実験 に供する菌液は約30分静置して粗大組織片が自然に沈下 するのを待って, その上清を別の滅菌試験管にとったも のを用いた。

2） 1 分間磨砕菌液：鼠瀨腫の一部を隇菌乳鉢に移 し，乳棒で正確に 1 分間軽く磨砕したのち，これに 0.1 \%牛血清アルブミン V-生塩水を注いで, あとは pipettingによって菌液としたもの。

3） 5 分間磨砕菌液 : 鼠癩腫を滅菌乳鉢で 5 分間磨砕
したもので,以下の操作は 1 分間磨砕菌液と同じくした。 4） 15分間磨砕菌液：鼠癩腫を隇菌乳鉢で15分間磨砕 したもの。

5）精製菌液：鼠癩腫からの鼠癩菌の集菌精製は森 6)らの方法に準じて次の方法で簡便に行なった。即ち, 鼠瀨腫を 5 分間滅菌乳鉢で磨砕し $10 \mathrm{ml}$ の滅菌生塩水を 注ぎ, 菌浮游液とした。これに $2 \%$ トリプシン（ 1 : 250 Difco） $2 \mathrm{ml}$ を加え, $37^{\circ} \mathrm{C} 30$ 分間消化後 $3,000 \mathrm{rpm} 1$ 時間30分遠心, 沈渣を生塩水 $4 \mathrm{ml}$ に再浮遊, これに 1 $\% \mathrm{NaOH} 4 \mathrm{ml}$ を加え2 3 回 pipetting ᄂ, 3,500 $\mathrm{rpm} 30$ 分間遠心, 沈渣を $4 \mathrm{ml}$ の $0.1 \%$ 牛血清 アルブミ ンV-生塩水に再浮游したものを精製鼠瀨菌菌液とした。 


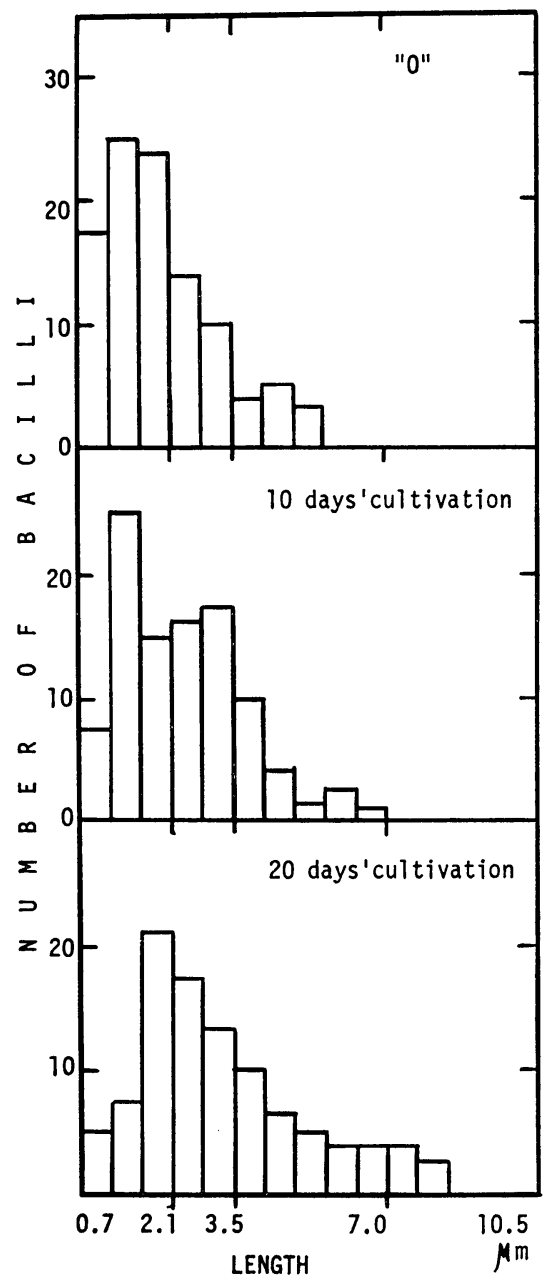

Five minutes' ground

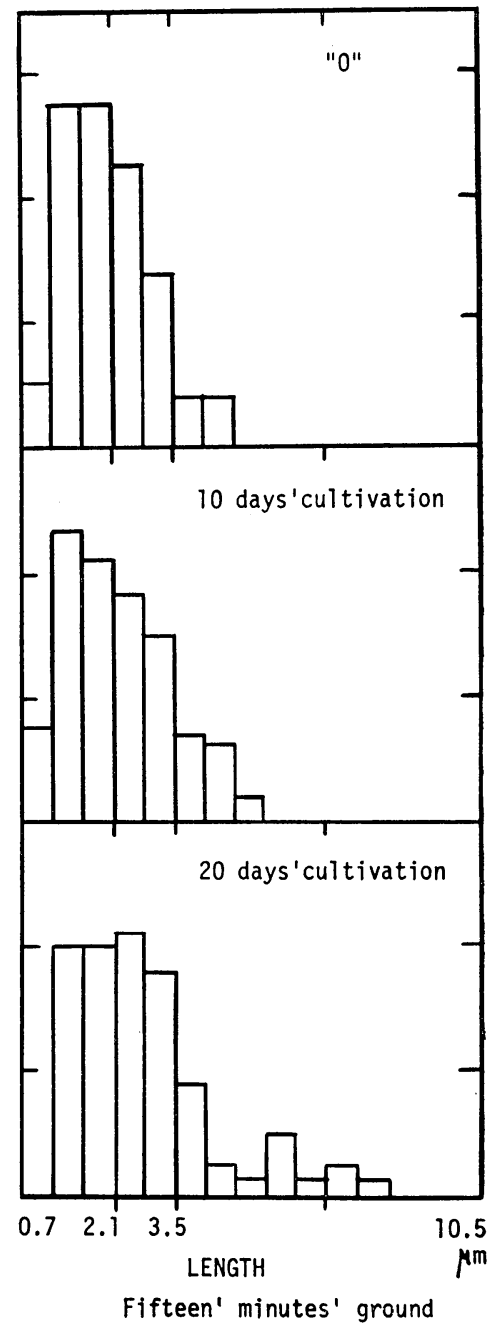

Fifteen' minutes' ground

Fig. 4 Distribution of lenght of $M$. lepraemurium

菌塗枺スライド : 以上のように作製した菌液をそれぞ れ滅菌した Bioden meshcement タンザクスライド(BM スライド)5の一端にマント一針をつけた注射器で一滴 宛滴下，菌塗抹スライドとした。菌液を BM スライド に滴下して約 30 分放置, 乾かない菌液を注射器で吸いと って，菌液が乾いたところで次の培地に塗抹端を下して 投入， $37^{\circ} \mathrm{C}$ で培養，10日 抢よび 20 日にスライドを取り 出し, 10\%ホルマリン水で固定後, 水洗, Ziehl一戸田染 色を施してこれを白黒の写真にとり，更に $1 \mu \mathrm{m} か ゙ 1 \mathrm{~mm}$ になるように引伸しておのおのの菌長を実測した。対照 としては出発材料の菌液塗抹 $\mathrm{BM}$ スライドを乾燥後直 ちにホルマリン水に固定したものの平均菌長をそれに当
てた。

培地：Kirchner 原法処方に $0.25 \%$ ブドウ糖， $0.25 \%$ 焦性ブドウ酸ソーダ， $7.5 \%$ 䓞糖を加えて $\mathrm{pH} 6$ 及び $\mathrm{pH}$ 7 に補正し滅菌したものに無菌的に $10 \%$ になるように牛 血清を加えた。Enriched Kirchner（EK）培地を用い， 試験管当りの培液量は $8.8 \mathrm{ml}$ とした。用いた試験管は 長さ $10.5 \mathrm{~cm}$, 径 $1.3 \mathrm{~cm}$ で培液 $8.8 \mathrm{ml}$ を入れると 液層 の高さは $7.0 \mathrm{~cm}$ になる。菌塗抹 $\mathrm{BM}$ スライド投入後は ゴム栓で密栓した。

\section{実験成綪}

1. 出発材料の菌長 
菌液作製法の異るによって出発材料の平均菌長が異 った。最も短かかったのは非磨砕菌液のそれで $2.0 \mu \mathrm{m}$ であり, 最も長かったのは部分精製された菌液の菌長で $2.7 \mu \mathrm{m}$ であった。その他， 1 分間磨砕菌液は $2.4 \mu \mathrm{m}$, 5 分間磨砕の分は $2.1 \mu \mathrm{m}, 15$ 分間磨砕菌液は $2.3 \mu \mathrm{m}$ で あった。

2. 培養後の菌長の変化

1) $\mathrm{pH} 6 \mathrm{EK}$ 培地における菌長の変化

前記 5 種類の菌液の $\mathrm{pH} 6 \mathrm{EK}$ 培地における菌長の変 化は図 1 のとおりである。非磨砕菌と精製菌の elongation が最も顕著であり，15 分間磨砕菌がこれに次ぎ， 1 分間磨砕と 5 分間磨砕の菌体の elongation は不良で あった。

\section{2) $\mathrm{pH} 7 \mathrm{EK}$ 培地における菌長の変化}

$\mathrm{pH} 7 \mathrm{EK}$ 培地における菌長は変化は図 2 に示すとお りで, $\mathrm{pH} 6 \mathrm{EK}$ 培地のそれと非常に異った成績を示し た。即ち, elongation の最も速かったのは非磨砕菌で あったが，20日間培養ではその延びがよくなかった。1 分間及び 5 分間磨砕菌は 10 日および 20 日間培養につれて スムーズに線状に elongate した。これに対して15分間 磨砕菌および精製菌の elongation は不良であった。

これらの成績をさらに出発材料，10日間培養および20 日間培養中の菌長とその菌数の分布をヒストグラムで示 すと図 $3 ， 4$ および 5 の通りである。非磨砕菌および特 に 1 分間磨砕菌では $2.1 \mu \mathrm{m}$ 以下の菌数が培養につれて 減少しているのが分り，このことは塗抹された菌の大部 分が一斉に elongate したことを示している。5 分間磨 砕菌では $2.1 \mu \mathrm{m}$ 菌の数の減少が前 2 者に比して少な い。しかし, elongate した菌も多い。15 分間磨砕菌およ び精製菌では $2.1 \mu \mathrm{m}$ 以下の減少が極めて少ないので elongateしえない菌がはじめから多く含まれていたこと を示している。

\section{考察}

この研究によって鼠癩菌の in vitro elongation の実 験を行ならさい用いられる菌液はどのように作製さるべ きかということが明瞭になった。即ち，なるべく温和な 方法でレプロームをこわして菌液を作るべきで，乳鉢を 全く用いないで八サミで細切するか, 乳鉢で磨砕するな らば 1 分間，長くても 5 分間以内の磨砕に止むべきであ る。このような mild な方法で作製した菌液を用いると 確実に再現性のある elongation を観察することが出来 る。

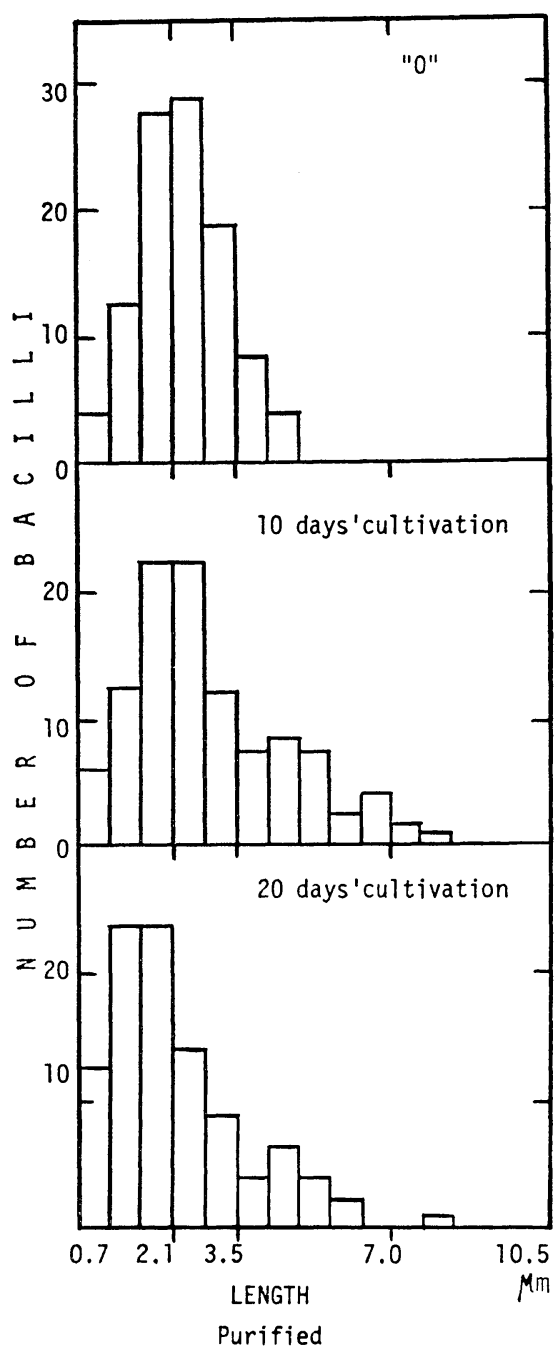

Fig. 5 Distribution of length of M. lepraemurium

換言すれば，鼠瀨菌は磨砕などの物理的処理に対して 極めて sensitive な脆弱な菌といえよう。このことは鼠 癩菌の培養実験のさい特に念頭においておかなければな らぬ特性である。現にこの後は非磨砕菌液を用いて研究 を続行中であるが，実に再現性ある鼠癩菌の elongation を認め得, 実験データーの処理と解決に進展と理 論性を与えることが出来ている。また，鼠癩腫の採取時 期などを考慮に入れれば, elongation の synchronize も可能だという印象を得ている。

これらの成績は動物接種の場合も当然考慮さるべきこ とで，感受性動物系統や接種部位の選択と共に発症のよ 
りよい画一性もこの方法によって得られるであろう。

以前まで elongation の研究に Kirchner 培地をもと にしたものを使用してきた。Hart \& Valentine ${ }^{7)}$ も大 略類似の培地を使用している。しかし，最近 ${ }^{5)}$ ，培養実 験を考えて Kirchner 培地にブドウ糖, 焦性ブドウ酸ソ ーダおよび蔗糖を加えて enrich したものを使用してい るが,このように enrich することにより elongation のパターンが全く変貌したことを感ずる。それはpH 6.0 では elongation が不良で $\mathrm{pH} 7.0$ での elongation が極 めて著明になったことである。

今回の実験でも同一の所見を得たが， pH 6 と $\mathrm{pH} 7$ 培地での elongation は或は全く異質のものではない かと思う。なぜならば今回の実験成績の示すように $\mathrm{pH}$ 6 での elongation は15分間磨砕菌と精製菌に認められ て，1 分間磨砕菌と 5 分間磨砕菌では極めて軽度であっ たのに反して, pH 7 培地ではこれと全く逆に 1 分間磨 砕菌と 5 分間磨砕菌に著明な elongation が認められた からである。

ただ，非磨砕菌の elongation は. pH 6 でも pH 7 で も10日培養では良好であったことに対しては未だ明確な 説明はできかねる。

\section{結 論}

鼠癩菌の in vitro elongation 実験に用いる菌液の作 り方で, 菌の elongation がどう影響されるかを検討し たところ, 次の結論を得た。

1. 鼠瀨菌を乳鉢で磨砕せずに，なるべく菌に障害を 与えない操作で作製した菌液と 1 分間乳鉢で磨砕して作 製した菌液中の菌体が最もよい elongation を示し，次
には 5 分間磨砕して作製した菌液中の菌体がスムーズな elongation を示した。しかし，15 分間磨砕菌液と部分 精製菌液の菌体の elongation は良好でなかった。

2. Enriched Kirchner 培地での elongation は前報 までに述べた Kirchner 培液での elongation と異ったパ ターンを示した。即ち, 前者では $\mathrm{pH} 7$ で, 後者では pH 6 で elongation が起った。

これらの結果は鼠攋菌の培養実験に多大の重要な資料 と示唆を与えたものと思われる。

本研究は日米医学協力計画ライ専門部会の研究費によ った。

\section{文献}

1) Nakamura, M. : Improved method for observing elongation of $M y c$. lepraemurium in vitro, Intern. J. Leprosy, 35 : 505-509(1967).

2) Nakamura, M. : 鼠癩菌の in vitro elongation に関する研究. レプラ, $38: 11-14(1968)$.

3) 中村昌弘：鼠癩菌の in vitro elongation に影 響を及ぼす因子、レプラ，37：162-169(1969).

4) Nakamura, M.: Effects of the depth of culture medium on elongation of Mycobacterium lepraemurium in vitro. Intern. J Leprosy, $38:$ 162-169).

5) 中村昌弘：鼠瀨菌の in vitro elongation: Bioden meshcement slide を用いての実験. レ プラ41:7-10 (1972)

6) 森 竜男, 高坂健二, 伊藤利根太郎, 西村真二 : 鼠癩菌の集菌法, 日本細菌学雑誌, $16: 808-813$ (1961).

7) Hart, P. D'Arcy and Valentine, R. C. : Growth of $M y c$. lepraemurium in cell-free medium. J. gen. Microbiol., 32 : 43-54(1963) 